\title{
AZ EGÉSZSÉGET VESZÉLYEZTETŐ ÉLETMÓD ÖSSZEHASONLÍTÓ VIZSGÁLATA KULTURÁLIS KÜLÖNBÖZŐSÉGEKET MUTATÓ FIATALOK KÖRÉBEN
}

\author{
Authors: \\ Csibi Sándor $(\mathrm{PhD})$ \\ University of Medicine, Pharmacy, \\ Science and Technology \\ (Targu Mures, Romania) \\ Csibi Mónika $(\mathrm{PhD})$ \\ University of Medicine, Pharmacy, \\ Science and Technology \\ (Targu Mures, Romania) \\ E-mail adress of the first author: \\ sandor.csibi@,umfst.ro
}

\author{
Lectors: \\ Pașca Maria Dorina (PhD) \\ University of Medicine, Pharmacy, \\ Science and Technology \\ (Targu Mures, Romania) \\ Mező Ferenc $(\mathrm{PhD})$ \\ Eszterházy Károly Egyetem (Magyarország)
}

Csibi Sándor, Csibi Mónika (2019): Az egészséget veszélyeztető életmód összehasonlító vizsgálata kulturális különbözőségeket mutató fiatalok körében. Különleges Bánásmód, 5. (3). 7-20.

DOI $\underline{10.18458 / \text { KB. } 2019.3 .7}$

\begin{abstract}
Absztrakt
A fiatalok és kulturális közösségeik életében egyre nagyobb hangsúlyt kapnak az egészségmegőrző, elsősorban életmódbeli tevékenységek. A kutatás célja azon viselkedési stratégiáknak a feltérképezése, amelyek az egészség megőrzését teszik lehetővé, valamint a társadalom és a környezet által hajlamosító kockázati magatartásformák megismerése. Az alkalmazott kérdôív demográfiai, életmódbeli, családi és iskolai környezetre, valamint kockázati tényezőkre vonatkozó kérdéseket tartalmaz. A vizsgálat résztvevői 280 fiatal Marosvásárhely és Eger tanintézeteinek XI-XII évfolyamairól. A vizsgálatot 2011 februárjában végeztük, rétegzett mintán, önkitöltős kérdőíves módszerrel. Eredményeink a földrajzi elhelyezkedés függvényében a két csoport között szignifikáns különbségeket mutattak az élettel való elégedettséget, az alkoholfogyasztás gyakoriságát illetôen, de a családi támasz, az iskolai elfogadás és a tanárok tanuló iránti attitűdje szerint is. A nemek szerint különbözik az egészség önértékelése, a szubjektív testkép, a testtömegkontrollálása, az alkoholfogyasztás gyakorisága és mennyisége, ugyanakkor az iskolai attitúd, az együttléti idő a barátokkal és a tanulók elfogadása a tanárok felől.
\end{abstract}

Kulcsszavak: egészséget veszélyeztető életmód, kulturális különbözőségek, élettel való elégedettség, családi és iskolai közösségek.

Diszciplínák: egészségtudományok, orvosi szociológia. 
KÜLÖNLEGES BÁNÁSMÓD, V. ÉVF. 2019/3.

\begin{abstract}
COMPARATIVE ANALYSIS OF YOUTH'S HEALTH-RISK LIFESTYLE IN THE PERSPECTIVE OF THEIR CULTURAL DIFFERENCES

Health-related, primarily lifestyle-associated activities are increasingly emphasized in the lives of young people and their cultural communities. The aim of the research is to explore behavioral strategies that maintain health and to understand those society and the environmental factors that predispose risk behaviors. The questionnaire includes items about demographics, lifestyle, family and school environment, and health risk factors. Participants are 280 youngsters from the 11-12 ${ }^{\text {th }}$ graders of Târgu-Mureş and Eger. The study was conducted in February 2011 on a stratified sample using a self-completed questionnaire method. Our results showed significant differences between the two groups in terms of life satisfaction, frequency of alcohol consumption, but also in terms of family support, school acceptance, and teachers' attitudes toward students. We found gender differences in health-related self-esteem, subjective body image, body weight control, frequency and amount of alcohol consumption, but also in school attitudes, time spent with friends.
\end{abstract}

Keywords: health-risk lifestyle, cultural differences, life satisfaction, family and school communities.

Disciplines: health sciences, medical sociology.

Az egészséges életmód és az egészségmagatartás egyre gyakrabban kutatott jelenség nemcsak hazánkban, hanem nemzetközi viszonylatban is. Ennek a kutatási irányzatnak a hátterében a gazdasági fejlődés elősegítésének és a társadalmi jól-lét megteremtésének célja áll, az életminőség javitása érdekében, ugyanis egy egészséget fenntartó magatartás egy nagyobb egyéni teljesítményt és általa gazdasági növekedést eredményez.

$\mathrm{Az}$ egészséges állapot napjainkban tőkének tekinthető, jelentősen hozzájárulva a nemzeti gazdaságok növekedéséhez, sőt a kutatások azt is kiemelték, hogy például a várható élettartam egy évnyi emelkedése négy százalékkal növelheti egy adott ország GDP-t (Kollányi és Imecs, 2007). Az egészség meghatározása Parsons (1951) felfogásában az egyén optimális teljesítóképességének állapota, mely képessé teszi azon szerepeinek és feladatainak betöltésére, amelyekre szocializálódott. Tehát az olyan ember egészséges, aki összhangban él környezetével, szociális és gazdasági értelemben aktív, ugyanakkor képes életterveit sikeresen megvalósítani. Ebben az értelemben a gyermekkori egészségi állapot is befolyásolja a későbbi tanulási képességeket, az iskolai teljesítményt, majd a társadalmi beilleszkedést és közvetett módon hatással van a gazdasági teljesítményre is. A serdülők fejlōdése a környező kulturális és intézményi kontextusban gyökerezik és általuk meghatározott. A kulturális és intézményi háttér hatása több szinten is megynilvánulhat, igy elemezhetjük ezt kultúrközi, történeti és társadalmon belüli (intraszocietális) megközelitésben. A serdülókor sajátosságai, valamint a fiatalokhoz iránti attitűdök és felfogások szorosan összefonódnak a szociális és gazdasági társadalmi szerveződésekkel, konstruktumokkal illetve ezek múködésével (Crockett, 1997).

Az egészség fogalmához kapcsolódó kérdések tisztázásában a kultúra elemzése sajátos szerepet tölt be - elősegíti és fokozza a kommunikáció hatékonyságát olyan multikulturális tartalmak révén, amelyek a fiatalok egészségét és jóllétét érintő problémákat hangsúlyozzák. Ilyenek például az egészséges életmód megtanulása és egészségügyi viselkedési ismeretek elsajátitása, az életmód és betegség összefüggéseinek ismerete, a társas támogatást, a 
lelki egészségfejlesztést és a tanácsadást biztosító programokban való résztvétel, amelyek az egészséggel kapcsolatos ismereteket, tudást és életkészségeket bővítik (mint az egészséges étkezés, a testedzésnek és a szabadidő hasznos eltöltése, az egészségmegőrző, környezetóvó attitűd kialakítása, az egészséges énkép és önbizalom kialakítása, a kudarctűrő - képesség növelése, önállóságra nevelés, stb.). (Kreuter és McClure, 2004).

Betancourt és Flynn (2009) úgy tartják, hogy az egészségtudományok szemszögéből, a kultúra olyan elemeknek összetevője, melyek az egészség fogalmát irják körül. A kultúrát tehát az egészségmagatartásra és az egészséget fenntartó tevékenységekre jellemző rejtett értékek, meggyőződések, normák, hiedelmek elvárások es cselekvések révén határozhatjuk meg. Pikó (2002) vizsgálatai is hangsúlyozzák, hogy az egészség kulcsa az életmódban rejlik. Az életmód alapelemei már a gyermekkorban kialakulóban vannak, serdülókorban jelentős változásokon mennek keresztül, majd stabilizálódva, meghatározzák az egészségi állapotunkat éketünk folyamán. A serdülőkori fejlődési szakaszra jellem-ző erôteljes testi és lelki, biológiai és lélektani valamint szociális változások befolyására kialakulnak azok az attitúdök és magatartásmódok, amelyek a jövő során kedvező vagy káros hatással lesznek az egészségi állapotunkra.

$\mathrm{Az}$ egészségi állapottal kapcsolatos életmód az egyének és közösségek általános és átfogó életmódjának részét alkotja. Az életmód tehát összefoglalja a társadalmi pozició jellemzőit, az adott közösség specifikumait és az egyén személyiségi tényezőit egyaránt (Pikó, 2002). Más kutatások szerint (Albert-Lőrincz E., 2009) az önpusztító viselkedésformák egyre gyakoribbá válnak a serdülők körében, olyan tényezôk negatív hatására, mint az életmódváltozás, a családok felbomlása, az erőszak terjedése az interperszonális kapcsolatokban, melyeket a megfelelő megküzdési stratégiák hiánya felerősít. Benkő (2005) felfogásában az egészséges életmódot az életválasztás és az életle- hetőségek fogalmainak segítségével tudjuk körülírni. Az életválasztás értelmezésében az emberek az egészséggel kapcsolatos döntéseiket motivációiknak megfelelően, valamilyen cél megvalósításának érdekében hozzák, így az egészséges életmód egy olyan teljesítménnyé válik, amit az egyén önmaga ér el. Az életlehetôségek értelmezése szerint az egyéneknek választási esélyeik vannak az egészséges életmódot illetôen, tehát az egyéni választás az egészségmagatartás meghatározója. Bourdieu (1978) a habitus fogalmát elsősorban életválasztáshoz kötődő, de az egészséggel kapcsolatos döntések mentén is értelmezi, olyan egészségfenntartó tevékenységek rendszereként, amelyek rutinszerủek, tudattalanul múködnek és megvalósulásuk által további megerősítést nyernek. Igy az egészségfenntartó habitusok időben állandósulnak és adott viselkedési mintázatot létrehozva alakítják az egyén életmódját. Andorka (2006) szerint minden társadalomban létrejön egy adott magatartási tendencia, amely meghatározza hogy az emberek egészségük fenntartása érdekében mennyi időt fordítanak olyan szabadidős tevékenységekre, mint a sportolás, szabad levegő́n végzett aktivitás, séta, stb.

Mivel emberi életünk a kultúra, a civilizáció terméke, így az életmód magatartási megnyilvánulásai az adott kultúra norma- és értékrendszerétől függenek. A kultúra tehát, hozzájárulhat egy populáció egészségéhez, de ugyanakkor káros hatásai révén meg is akadályozhatja azt (Kopp és Pikó, 2003). Az egészségkultúra jelentôsen befolyásolja az egészségmagatartást, amely az általános kultúra részét képezi és fokozatosan beépül a személyiségbe. Az egészségkultúra jelentős növekedéséhez hozzá járul a már kisiskoláskorban elkezdődő alakítása, mint amilyen, a személyi és környezeti mentálhigiénés szabályok széles körú ismerete és alkalmazása. Az aktuális egészségpszichológiai törekvések érvényesítése az iskolák életében elengedhetetlenül szükséges egészségkultúra megalapozásához (Albert-Lőrincz E., 2000). A serdüló- 
kor egyértelmúen befolyásolt a szociális és gazdasági tényezők által és az adott kulturális és történelmi kontextus függvényében különbözően nyilvánul meg, azonban bizonyos átmeneti szakaszok azonosnak mutatkoznak a legtöbb társadalomban (Coleman, 1990). Crockett, (1997) szerint szoros kapcsolat áll fenn a serdülőkori sajátosságok és a társadalmi rendszer tényezői között, igy nemcsak a kognitiv fejlődés, de a serdülók tapasztalatai is eltérôek lesznek az adott kulturális és történelmi kontextustól függően. Ugyanakkor a felnőtté válás folyamatában, a serdülőkori fejlődés alatt elsajátitandó képességek és kialakitandó kompetenciák is az adott kulturális és történelmi kontextus által meghatározottak.

A heterogén társadalmakban az ökológiai kondiciók változásai összefonódva a serdülőkori fejlődés sajátosságaival jelentős meghatározóivá válnak a serdülők egészségi állapotának és élet perspektiváinak. Különösen befolyásolják azokat az egészségkockázati tényezőket amelyekkel szembesülnek a serdülők, valamint a protektiv faktorokat is amelyek védő hatással lehetnek ezekkel a kockázatokkal szemben (Crockett, 1997).

Cockerham elméletében (2005) az egészségmagatartás a gazdasági környezet és az adott szociális kultúra által meghatározott szocializációs folyamat eredménye, így a rizikómagatartás is a negatív irányú szocio-kulturális megerôsítések hatására alakul ki. (Cockerham, 2005)

Az egészségkutatások a kultúrát gyakran csak a nemzetiségi, faji, nemi vagy szocioökonómiai státusz (SES) katagóriái mentén azonositják, pedig szükség lenne sokrétúbb, érzékenyebb megközelitési eszközökre.

Ebből a szükségletből kiindulva, Betancourt és Flynn (2009) egy olyan modellt alkottak, amelyben az egészségmagatartás kutatása céljából kulturális, pszichológiai és viselkedési tényezőket is figyelembe vesz (1. ábra).

1. ábra: Betancourt modellje szerint a kultúra aspektusai (B) közvetlenül/közvetve a pszichológiai folyamatok által (C) befolyásolják az egészségmagatartást (D) a különbözó népesség kategóriák esetében (A). (Forrás: Betancourt és Flynn, 2009)

\begin{tabular}{|c|c|c|c|}
\hline $\begin{array}{l}\text { Népesség } \\
\text { kategóriák }\end{array}$ & $\begin{array}{l}\text { Kulturális } \\
\text { tényezők }\end{array}$ & $\begin{array}{l}\text { Pszichológiai } \\
\text { folyamatok }\end{array}$ & $\begin{array}{l}\text { Egészség- } \\
\text { magatartás }\end{array}$ \\
\hline $\begin{array}{l}\text { Faj Etni- } \\
\text { kum } \\
\text { Nem } \\
\text { SES Val- } \\
\text { lás }\end{array}$ & $\begin{array}{l}\text { Társadalmi } \\
\text { közös érté- } \\
\text { kek, hiedel- } \\
\text { mek, elvárá- } \\
\text { sok }\end{array}$ & $\begin{array}{l}\text { Motivációk } \\
\text { kogníciók } \\
\text { érzelmek }\end{array}$ & $\begin{array}{l}\text { Egészség } \\
\text { fenntartó } \\
\text { cselekvések, } \\
\text { viselkedések }\end{array}$ \\
\hline $\mathbf{A}$ & B & C & D \\
\hline
\end{tabular}


Mindenki része egy adott kultúrának és ugyanakkor több szubkultúrának egyidőben. A kultúrát a társadalom tagjai a gyerekkori szocializáció során sajátítják el, de a szocializációs folyamat az egész élet során folytatódik (Andorka, 2006). A meghatározó kultúraforma a nemzeti kultúra, de ugyanakkor több kisebb-nagyobb kulturális csoport részei vagyunk, mint a nemzedék, a nem, a vallás, a településfajta, az értékrendszer, a család, az intézmény, a lakónegyed, stb., melyek meghatározott és sajátságos kultúrával ruháznak fel. A kulturális „másság” a tárgyi környezet, a mozgástér és a térkihasználás, az időháztartás, az emberi kapcsolatok, a kommunikáció, az emberi célok, ambíciók, a konfliktusok és a konfliktus-megoldási stratégiák, a privát szféra, az intimitás, illetve a nyilvánosság határai, az egészség, a nemi szerepek, a vallás, a hatalom, stb. terén nyilvánulhat meg. Úgy is mondhatjuk, hogy a kultúra anyagi, kognitív és normatív elemekből tevődik össze, vagyis tárgyakból, tudásból, szimbólumokból, értékekből és normákból (Andorka, 2006).

Kapitány Á. és Kapitány G. (1996) munkája szerint egy más kultúra látható, tárgyi jelekben megnyilvánuló különbözőségei több ponton érzékelhetóek, de legmélyebben ott élhetők át, ahol az ember szocializációjának érzelmi elemeibe ütköznek más belső értékek, mint amiket gyermekkorban interiorizáltunk. A két szerző szerint Magyarországon jelenleg is zajló kultúraváltás, egy olyan individualizációs és modernizációs folyamat, amely a nyugati államok kultúrájához való csatlakozást követi.

Az individualizáltabb kultúrák számára az iskolai rendszer erősségei a gyakorlatiasságra való összpontosítás, a specializálódás, egyre szakosodottabb tanítás eszközeivel. A nevelés szempontjából ugyanakkor elsődleges szempont, a gyerek erős oldalainak, speciális képességeinek és tudásának kiaknázása, erre való pedagógiai építkezés. Igy méginkább megerősödik a gyerek öntudata, könnyebben szembesül a kihívást jelentő versenyhelyzetekkel és érvényesül ezekben. (Kapitány Á. és Kapitány G., 1996). Papp (2005) szemléletében az iskolai teljesítményt a szülői háttér, az ifjúsági kultúra, valamint az iskolai kultúra (például a diákoknak az iskoláról alkotott véleménye, az iskola teljesítményorientált légköre) is befolyásolja.

A serdülők napjainkban olyan ifjúsági kultúra részei, amelyre regionális, illetve a családi háttérrel kapcsolatos sajátosságok is épülnek, befolyásolva az iskolai teljesítményt, az iskolai kapcsolatokat, valamint az iskolai környezetben elsajátított életmódbeli sajátosságokat, beleértve az egészségmagatartási habitusokat is. A szerfogyasztási, valamint a dohányzási szokások kialakulása a fiatalok individualizációjának mércéje, valamint a különböző társas kapcsolatok sajátosságainak kifejezője is lehet. A társas támogatás elősegíti a serdülók iskolai környezetbe, majd társadalomba való beilleszkedését és szoros összefüggésben van az életminőség alkotóelemeivel.

A kutatók szerint (Pierce és mtsai. 1990) a társas támogatás a szociális tranzakció egyik formája, amelynek célja az egyén megsegítése a mindennapi életben, különös tekintettel a kritikus élethelyzetekre. A családnak jut a legfontosabb szerep a serdülő életében, hiszen a kultúra átadásán kívül anyagi és érzelmi támogatást is jelent egyidőben. Andorka (2006) szintén kiemeli a szülői házban és a kortárs csoportban elsajátított kultúra szerepét, mely szerinte annyira meghatározó, hogy az iskolai oktatás sem képes megváltoztatni.

Spéder és Kapitány (2002) az élettel való elégedettséget vizsgálva, a társadalmi, a családi és a baráti kapcsolatok pozitív hatását emelték ki, hangsúlyozva ugyanakkor az egészségi állapottal való elégedettség szerepét az élettel való általános elégedettség generálásában. Egy élethelyzet vagy egy magatartás akkor tekinthető rizikótényezőnek, ha a serdülők rosszabb alkalmazkodását vetíti előre.

Az egészségmagatartás társas kontextusának (családi támasz, az iskolai környezet hatása és a 
kortárskapcsolatok) és az egészségre káros magatartásformáknak feltérképezése jelentős támpontokat nyújtanak számunkra a serdülők életmódbeli struktúráinak megértésében. Ugyanakkor az egészségmegőrző, életmódbeli tevékenységek, mint a rendszeres testmozgás vagy a testtömegkontrollálására irányuló aktivitás egyre nagyobb teret nyernek a serdülők körében.

Brassai és Pikó, (2007) serdülőkön végzett kutatásai hangsúlyozzák a protektív pszichológiai hatások szerepét a fiatalok egészségtudatos viselkedésének kialakításában, illetve az egészségkockázati magatartásformák megelőzésében. Crockett, (1997) úgy tartja, hogy az egészséget veszélyeztető cselekvés strukturák többnyire önkéntesen hajtódnak végre a serdülők által (például a dohányzás, a szerhasználat, az agresszió bizonyos formái). Ebből a szempontból kritikus fontosságú a megfelelő nevelés és orientáció biztositása, a fiatalok motivációjának és foglalkozási lehetőségeinek növelése mellett, elősegitve igy a kockázati viselkedés elkerülését.

Az aktuális demográfiai környezet, amelyre jellemző lett a családi vezetést átvevő nők vagy az egyszülős családszerkezetek sokszorozódása, a szegénység megnövekedése, valamint a lakhatási szegregáció térhóditása, gyakran elszigeteli a serdülóket a számukra meghatározó erőforrásoktól és szerepmodellektől, jelentősen megnövelve a fontosabb életcélok megvalósitásához szükséges erőfeszitéseket (Crockett, 1997). A fiatalok egészségmagatartását befolyásoló tényezőket célzó kutatások is egyre gyakrabban összpontositanak a nemi és szociogazdasági státusz szerepére, társitva ezeket az egészséget befolyásoló döntésekkel (Tyc és mtsai. 2004).

A jelenkori társadalmi változások negativ hatásainak eredményeként a serdülók életmódjában egyre több az egészségre káros magatartásforma. Mivel serdülókorban az egészségmagatartás a pszichoszociális fejlődés igen fontos összetevője, érdemes odafigyelni a korra jellemző, valamint az életmódjukra ható szocio-kulturális tényezőkre is.
Pikó (2010) szerint számos kockázati tényező olyan mélyen gyökerezik a társadalmi struktúrákban, hogy a modern kultúrában való megváltoztatásuk nagy nehézségekbe ütközik vagy akár nem is lehetséges. Kutatások szerint a gyermekkor késöi és a serdülőkor korai időszakában a kockázati magatartások aránya jelentôsen megnövekedik, párhuzamosan az egészségmagatartás csökkenésével. Ezeknek a viselkedésformáknak korai életszakaszokban való kialakulása meghatározza azokat a szokásokat, értékeket és azt az életstilust amelyek majd stabilizálódnak és kibővülnek a későbbi fejlődési szakaszok során. (Maggs és mtsai., 1997). Woodgate és Leach (2010) vizsgálataiban a serdülők az egészségi állapot meghatározásában rámutattak arra, hogy az élethelyzetük az amely elősegiti vagy meggátolja az egészséges életstilus gyakorlásának képességét. A fiatalok leggyakrabban az egészségi állapotot cselekvésként határozzák meg, „valami jónak megtevéseként”, mint például egészségesen étkezni vagy sportformát gyakorolni.

A személyes életstílus kialakitásának tekintetében pedig kiemelték az egyensúlyra való törekvést, ami a káros cselekvések elkerülését (pl. snack vagy zsíros és cukros élelmiszer fogyasztása) és az egészségesként észlelt cselekvések gyakorlását (testmozgás, sport gyakorlása) jelenti számukra.

Összefoglalva elmondhatjuk, hogy a serdülők tapasztalatai teljességükben a kulturális, intézményi és gazdasági minták, patternek által meghatározottak. Ezek a kulturális tényezők előrevetitik a fiatalok által gyakorolt szerepeket, magatartás konstruktumokat és tevékenységeket, meghatározva ugyanakkor a serdülőkori életszakaszra jellemző elakadásokat, határokat is.

Ezáltal jelentősen befolyásolják a serdülőkor mint fejlődési szakasz „státuszát” valamint ennek a közérthetőségét, átláthatóságát is. (Crockett, 1997). Elsősorban a kultúra, a modern társadalom sajátosságai határozzák meg tehát, hogy testileg és lelkileg egészségesebb tagai lesznek vagy sem. (Pikó, 2010) 


\section{Módszer}

\section{Cél}

A kutatás célja azon viselkedési stratégiáknak feltérképezése, amelyek az egészség megőrzését teszik lehetővé, valamint a társadalom és a környezet által hajlamosító kockázati magatartásformák megismerése.

A serdülőkori egészséget veszélyeztető életmód azon tényezőit vizsgáljuk, melyek eredete a földrajzi elhelyezkedés kulturális különbözőségeiből fakadnak. Az egészséges életmód szocio-kulturális jellegzetességeinek, rizikófaktorainak ismerete a serdülőkori kockázati életmód csökkenését, prevencióját eredményezheti.

\section{Hipotézisek}

- Az egészségmagatartás protektív tényezői jelentős korrelációkat mutatnak a nem függvényében,

- Az életkor előrehaladásával csökken a serdülők protektív magatartásainak száma, ugyanakkor növekszik a kockázati viselkedések gyakorisága,

- A földrajzi elhelyezkedés és a kulturális különbözőség jelentôs változásokat eredményez a serdülők egészséges életmódjában.

\section{Minta}

A vizsgálat résztvevői 280 erdélyi (Marosvásárhely) és magyarországi (Eger) fiatal a 17-18 éves korcsoportból, átlag életkoruk 17,4 év volt. A vizsgálatot 2011 februárjában végeztük, rétegzett mintán, önkitöltős kérdőíves módszerrel. A résztvevőket az iskolai osztályok 11 és12 évfolyamairól, véletlenszerű (random) módon választottuk ki. A kérdőíveket anonim módon, iskolapszichológus segítségével, osztályfönöki órákon vettük fel. A kérdőív kitöltése 40-50 percet vett igénybe.

\section{Eszközök}

Az általunk alkalmazott egészségkutatási kérdőív demográfiai, életmódbeli, családi és iskolai környezetre, valamint szerhasználatra vonatkozó kérdéseket tartalmaz. A kérdések az Egészségügyi Világ Szervezet (WHO) által Magyarországon és Romániában is alkalmazott HBSC Survey kutatások kérdéscsomagját veszik alapul (Aszmann A., 2003, után). A kapott adatok szocio-kulturális összehasonlítást tesznek lehetővé, mert társadalmi és kulturális szinten különböző országok serdülőinek életmódját és egészségmagatartását hasonló módszerrel, ugyanazon kérdések által vizsgálták.

Az általunk vizsgált serdülőkori egészségmagatartás hat elemből állt; három egészségvédő (protektív) formából (fizikai aktivitás, testtömegkontrollálására irányuló magatartás és élettel való elégedettség) és három egészségkárosító (kockázati) formából (dohányzás, alkohol- és drogfogyasztás). Elemeztük a serdülőkorú fiatalok önminősített egészségi állapotát, valamint társas kontextusát: a családban kapott támogatást, az iskolai környezet hatását és a kortárskapcsolatok szövődményét is, egy minél komplexebb, átfogóbb helyzetkép megtalálása érdekében.

Demográfiai adataink a nemet, az életkort (osztályt), a családszerkezetet, a szülők iskolai végzettségét, az iskolatípust (humán szak) és a földrajzi elhelyezkedésből (Erdély, Maros megye - Magyarország, Heves megye) eredő kulturális különbözőséget vették figyelembe.

Az egészségmagatartás elemei a következők voltak:

- a fizikai aktivitásra vonatkozóan a rendszerességet és a mennyiséget,

- az énképen belül a szubjektív testképet, az önértékelést (Rosenberg énkép skála) és a testtömeg kontrollálására irányuló magatartást,

- a rizikómagatartások közül a dohányzás, az alkoholfogyasztás és a drogfogyasztás kipróbálását és gyakoriságát kérdeztük, 
- a szubjektív jól-lét mutatói közül az önminősitett egészségi állapotot és az élettel való elégedettséget (WHO Jól-lét Kérdõív - WBI-5), mértük kérdéseink által. A WBI-5 kérdôiv magyar változata Susánszky É., Konkoly-Thege B., Stauder A., Kopp M. (2006) szerint megbízható és érvényes mérőeszköznek bizonyult a pozitív életminőség vizsgálatakor.

- A társas kapcsolatok és a társas támogatás feltérképezése a következő témaköröket célozta:

- a családon belüli támogatást (problémamegbeszélést a családtagokkal),

- az iskolai környezet jellemzőit, mint az iskola iránti attitűd, az iskolai terhelés, az osztályközösség percepciója, a tanárok és az osztálytársak megítélése,

- a kortárs kapcsolatok számát és az együttléti időt.

Az életmódbeli elemek adatait (protektív és rizikó tényezők szerint csoportosítva) a földrajzi elhelyez- kedés függvényében (kultúrafüggőség) hasonlítottuk össze, de az Egészségügyi Világ Szervezet

(WHO) kutatásoknak a két országra kapott adatait vettük viszonyítási alapul. Az adatok feldolgozását az SPSS programcsomag 11.5 verziójával végeztük.

\section{Eredmények}

Eredményeink a demográfiai változók mentén vannak kihangsúlyozva: nem, életkor, családszerkezet, a szülők iskolai végzettsége és a földrajzi elhelyezkedésből fakadó kulturális különbözőség szerint.

A válaszolók eloszlása: fiúk 36,1\%, lányok 63,9 \%; 17 éves (XI-ik osztályos) 52,5 \%, 18 éves (XIIik osztályos) tanulók 47,5\%; erdélyi (marosvásárhelyi) $48,6 \%$, valamint magyarországi (egri) serdülők $51,4 \%$.

A válaszolók neme szerint (1. táblázat) szignifikánsan különbözik az egészség percepciója, a globális önértékelés, a szubjektív testkép értékelése, a testtömeg-kontrollálására irányuló magatartás és az alkoholfogyasztás mennyisége.

\section{1. táblázat. Az egészségvédō tényezőle és a nem közötti összefüggés. (Forrás: Szerzoók)}

\begin{tabular}{|c|c|c|c|c|c|c|}
\hline Egészségvédő tényezők & Nem & $\mathbf{N}$ & Átlag & Szórás & $t$ & $\mathrm{p}$ \\
\hline \multirow[t]{2}{*}{ Az egészség önértékelése } & fiú & 101 & 2,02 & 0,75 & \multirow[t]{2}{*}{$-2,81$} & \multirow[t]{2}{*}{0,00} \\
\hline & lány & 179 & 2,26 & 0,64 & & \\
\hline \multirow[t]{2}{*}{ A testalkat önértékelése } & fiú & 101 & 2,88 & 0,74 & \multirow[t]{2}{*}{$-3,92$} & \multirow[t]{2}{*}{0,00} \\
\hline & lány & 179 & 3,25 & 0,77 & & \\
\hline \multirow[t]{2}{*}{ A globális önértékelés } & fiú & 101 & 29,52 & 5,36 & \multirow[t]{2}{*}{3,62} & \multirow[t]{2}{*}{0,00} \\
\hline & lány & 179 & 27,00 & 5,71 & & \\
\hline \multirow{2}{*}{$\begin{array}{l}\text { A súly szabályozása } \\
\text { (fogyókúra, mozgás) }\end{array}$} & fiú & 101 & 1,96 & 1,36 & \multirow[t]{2}{*}{$-2,73$} & \multirow[t]{2}{*}{0,00} \\
\hline & lány & 179 & 2,44 & 1,45 & & \\
\hline \multirow[t]{2}{*}{ Az alkoholfogyasztás mennyisége } & fiú & 101 & 3,45 & 1,49 & \multirow[t]{2}{*}{3,67} & \multirow[t]{2}{*}{0,00} \\
\hline & lány & 179 & 2,80 & 1,38 & & \\
\hline
\end{tabular}


KÜLÖNLEGES BÁNÁSMÓD, V.ÉVF. 2019/3.

Eredményeink összhangban vannak más kutatások-kal, melyek szerint azok a fiú és lány serdülők, akik kevésbé lázadóak és jobb egészségpercepcióval rendelkeznek, egészségesebb viselkedési szokásokról számolnak be (Tyc és mtsai., 2004).

Szignifikáns különbségeket észlelhetünk (2. táblázat) a nemek függvényében a családi támasz az édesapa részéről, a családi támasz a nővérek részéről, az iskola iránti attitűd, a diákok személyiségének elfogadása (a tanárok által), valamint az együttléti idő a barátokkal tényezők szempontjából is. A válaszolók életkora függvényében szignifikáns különbség van az olyan kockázati magatartások, mint a drogfogyasztás kipróbálása $(\mathrm{t}=-2,53$, $\mathrm{p}=0,01)$, valamint az etnobotanikus (herbál) drogok kipróbálása $(\mathrm{t}=-2,64, \mathrm{p}=0,01)$ között. Ha a társas kontextust vizsgáljuk az életkor függvényében (3. táblázat), a családi támasz a nôvérek részérôl, az iskolai elfogadás és a diákok személyiségének elfogadása esetében szignifikáns különbségeket találtunk.

2. táblázat. A társas kontextus és a nem közötti összefüggés. (Forrás: Szerzőo).

\begin{tabular}{|c|c|c|c|c|c|c|}
\hline Társas támogatás & Nem & $\mathbf{N}$ & Átlag & Szórás & $\mathbf{t}$ & $\mathrm{p}$ \\
\hline \multirow[t]{2}{*}{ Családi támasz (édesapa részérôl) } & fiú & 101 & 1,66 & 0,47 & \multirow[t]{2}{*}{$-2,77$} & \multirow[t]{2}{*}{0,00} \\
\hline & lány & 179 & 1,81 & 0,39 & & \\
\hline \multirow[t]{2}{*}{ Családi támasz (nôvérek részéről) } & fiú & 101 & 1,92 & 0,27 & \multirow[t]{2}{*}{1,97} & \multirow[t]{2}{*}{0,05} \\
\hline & lány & 179 & 1,83 & 0,36 & & \\
\hline \multirow[t]{2}{*}{ Iskola iránti attitűd } & fiú & 101 & 2,34 & 0,92 & \multirow[t]{2}{*}{3,34} & \multirow[t]{2}{*}{0,001} \\
\hline & lány & 179 & 1,99 & 0,79 & & \\
\hline \multirow[t]{2}{*}{ Tanárok tanuló iránti elfogadása } & fiú & 101 & 3,04 & 0,84 & \multirow[t]{2}{*}{$-2,03$} & \multirow[t]{2}{*}{0,044} \\
\hline & lány & 179 & 3,26 & 0,96 & & \\
\hline \multirow[t]{2}{*}{ Együttléti idő a barátokkal } & fiú & 101 & 4,23 & 1,51 & \multirow[t]{2}{*}{2,30} & \multirow[t]{2}{*}{0,02} \\
\hline & lány & 179 & 3,80 & 1,51 & & \\
\hline
\end{tabular}

3. táblázat. A társas kontextus és az életkor közötti összefüggés. (Forrás: Szerzőo).

\begin{tabular}{|l|c|c|c|c|c|c|}
\hline \multicolumn{1}{|c|}{ Társas támogatás } & Életkor & $\mathbf{N}$ & Átlag & Szórás & $\mathbf{t}$ & $\mathbf{p}$ \\
\hline \multirow{2}{*}{$\begin{array}{l}\text { Családi támasz (nővérek ré- } \\
\text { széről) }\end{array}$} & 17 év & 147 & 1,82 & 0,37 & $-1,97$ & 0,04 \\
\cline { 2 - 6 } & 18 év & 133 & 1,90 & 0,28 & & \\
\hline \multirow{2}{*}{ Iskolai elfogadás } & 17 év & 147 & 2,11 & 0,88 & $-2,14$ & 0,033 \\
\cline { 2 - 6 } & 18 év & 133 & 2,35 & 1,03 & & \\
\hline \multirow{2}{*}{$\begin{array}{l}\text { Tanárok tanuló iránti elfoga- } \\
\text { dása }\end{array}$} & 17 év & 147 & 3,05 & 0,96 & $-2,46$ & 0,015 \\
\cline { 2 - 5 } & 18 év & 133 & 2,32 & 1,47 & & \\
\hline
\end{tabular}


KÜLÖNLEGES BÁNÁSMÓD, V. ÉVF. 2019/3.

A családszerkezet vizsgálata az egészségvédő tényezők függvényében kiemeli, hogy szignifikáns különbségek vannak az édesanya jelenléte a családban és az életminőség önértékelése $(\mathrm{t}=2,06$, $\mathrm{p}=0,04)$ között, valamint a testvérek jelenléte a családban és az egészség önértékelése ( $\mathrm{t}=-1,90$, $\mathrm{p}=0,05)$, valamint a testalkat önértékelése $(\mathrm{t}=-2,53$, $\mathrm{p}=0,01)$ között.

A szülők iskolai végzettségének vizsgálata szignifikáns összefüggések emel ki az édesanya iskolai végzettsége és az életminőség önértékelése $(\mathrm{F}=2,77, \mathrm{p}=0,01)$ között, valamint a globális önértékelés $(\mathrm{F}=2,79, \mathrm{p}=0,01)$ között, ugyanakkor az édesapa iskolai végzettsége és a globális önértékelés $(\mathrm{F}=2,96, \mathrm{p}=0,02)$ között.

A földrajzi elhelyezkedés és az egészségvédő tényezők kapcsolatának függvényében a két csoport között szignifikáns különbségeket találtunk az élettel való elégedettséget ( $\mathrm{t}=-2,95, \mathrm{p}=0,00)$ és az alkohol-fogyasztás gyakoriságát $(\mathrm{t}=-3,26, \mathrm{p}=0,00)$ illetően. Ugyanakkor a földrajzi elhelyezkedés és a társas kontextus függvényében (4. táblázata) a családi támasz az édesanya részérôl, a családi támasz az édesapa részérôl, a családi támasz a nővérek részéről, az osztálylégkör, az iskolai elfogadás és a tanárok tanuló iránti attitűdje szerint szignifikáns különbségeket találtunk.

A bemutatott adatokon kívül több változó mentén is statisztikailag nem szignifikáns, de kimutatható különbségeket észleltünk a minta két vizsgálati csoportja között, a protektív és a rizikó tényezők, valamint a társas támogatás elemzett adatai szerint.

\section{Megbeszélés}

Serdülőkorban az egészséges életmód különbözőségeket mutat a nem szerint, igy mondhatjuk, hogy a fiúk jobb egészségi állapotról számolnak be, jobb a globális önértékelésük, mint a lányoknak, ugyanakkor többet és rendszeresebben mozognak, valamint hogy a lányok testalkatukat kedvezőtlenebbül ítélik meg, és a testtömeg kontrollálására tett erőfeszítéseik is nagyobbak. A serdülőkori idôszak jelentôsen befolyásolja a testképet és az önértékelést (Csibi és Csibi, 2013).

4. táblázat. A társas kontextus és a földrajzi elbelyezkedés közötti összefüggés. (Forrás: Szerzớk)

\begin{tabular}{|c|c|c|c|c|c|c|}
\hline Társas támogatás & Helység & $\mathbf{N}$ & Átlag & Szórás & $t$ & $\mathrm{p}$ \\
\hline \multirow{2}{*}{$\begin{array}{l}\text { Családi támasz } \\
\text { (édesanya részéről) }\end{array}$} & Eger & 144 & 1,38 & 0,54 & \multirow[t]{2}{*}{$-2,01$} & \multirow[t]{2}{*}{0,04} \\
\hline & Marosvásárhely & 136 & 1,51 & 0,50 & & \\
\hline \multirow{2}{*}{$\begin{array}{l}\text { Családi támasz } \\
\text { (édesapa részéről) }\end{array}$} & Eger & 144 & 1,70 & 0,45 & \multirow[t]{2}{*}{$-2,25$} & \multirow[t]{2}{*}{0,02} \\
\hline & Marosvásárhely & 136 & 1,81 & 0,38 & & \\
\hline \multirow{2}{*}{$\begin{array}{l}\text { Családi támasz } \\
\text { (nővérek részéről) }\end{array}$} & Eger & 144 & 1,82 & 0,38 & \multirow[t]{2}{*}{$-2,11$} & \multirow[t]{2}{*}{0,03} \\
\hline & Marosvásárhely & 136 & 1,91 & 0,28 & & \\
\hline \multirow[t]{2}{*}{ Osztálylégkör } & Eger & 144 & 2,82 & 0,94 & \multirow[t]{2}{*}{$-1,91$} & \multirow[t]{2}{*}{0,057} \\
\hline & Marosvásárhely & 136 & 3,02 & 0,82 & & \\
\hline \multirow[t]{2}{*}{ Iskolai elfogadás } & Eger & 144 & 2,06 & 0,90 & \multirow[t]{2}{*}{$-2,96$} & \multirow[t]{2}{*}{0,003} \\
\hline & Marosvásárhely & 136 & 2,40 & 0,99 & & \\
\hline \multirow{2}{*}{$\begin{array}{l}\text { Tanárok tanuló iránti at- } \\
\text { titűdje }\end{array}$} & Eger & 144 & 3,02 & 0,89 & \multirow[t]{2}{*}{$-2,47$} & \multirow[t]{2}{*}{0,014} \\
\hline & Marosvásárhely & 136 & 3,28 & 0,86 & & \\
\hline
\end{tabular}


Vizsgálatok szerint (Williams és Currie, 2000) a testkép mediálja a serdülőkori sajátosságok hatását az önértékelésre, igy a testsúly, valamint a rosszabb megjelenéssel kapcsolatos foglalatosság előrejelző értékủ az énkép alacsony szintjére. Eredményeink szerint a fiúk körében nagyobb a kockázati magatartások száma, köztük az alkoholfogyasztás mennyisége is.

Az életkor függvényében az egészségvédő magatartás tényezői között nincs szignifikáns különbség, elfogadás és a diákok személyiségének elfogadása (a tanárok által) tényezôknél, így a kisebb tanulók jobban szeretik az iskolájukat, tehát az iskolai elfogadás szintje náluk nagyobb, az osztálylégkör s viszont a XII-ik osztályban jobb, valamint a kisebb osztályok tanulói tanáraikat igazságosabbnak látják, viszont a nagyobbak szerint tanáraikat nagyobb mértékben érdekli a tanulók egyénisége. Ugyanakkor az iskolai megterhelés az évfolyamon való előrehaladás mértékével arányosan növekedik.

A család támaszfunkcióját az egészségmagatartás protektív tényezői között vizsgáltuk, a társas kontextus függvényében, nem, életkor és kulturális különbözőség szerint. Számos vizsgálat hangsúlyozta, hogy a család az egyik legfontosabb tényező a gyerek értékrendszerének, életmódbeli szokásainak és attitűdjeinek kialakulása szempontjából, melyeket a szocializáció során sajátít el. A kutatások szerint (Michael és Ben-Zur, 2007) a szülói stilus előrejelzi a jól-létet a szociális kompetenciák, a tanulási teljesitmény, a pszichológiai fejlődés és a problémás viselkedés területein belül. A szubjektív jóllét különböző komponenseit elemezve, Sallai (2005) eredményei kimutatták, hogy a különféle szocializációs közegekben átélt igazságosság és az igazságosság motívuma önmagában jelentős hatótényezőket képviselnek a serdülők mentális egészségének biztosításában. Ugyanakkor a serdülőkori fejlődés, az átélt életkrízisek fizikai, lelki, érzelmi és szociális változásokat eredményeznek (Chen és Faruggia, 2002), melyek áthidalása érdekében fontos szerepet játszik a család de a kapott adatok szerint az egészség önértékelése jobb a nagyobb (XII osztályos) tanulók esetében, de az életüket jobbnak látják a kisebb (XII osztályos) diákok, a fizikai aktivitás rendszeressége és mennyisége is nagyobb a fiatalabb tanulóknál, valamint a testalkat önértékelése jobb a nagyobb diákoknál, és ugyanakkor többet tesznek a testtömeg szabályozása érdekében is.

Az életkorra jellemző társas kontextus esetében szignifikáns különbségeket találtunk az iskolai támaszfunkciója, amely akkor lehet eredményes, ha a család teljes, múködése harmonikus, kiegyensúlyozott. Pikó és Hamvai (2009) kutatásai szerint azok a fiatalok, aki életükkel elégedettebbek és optimistábbak, jobbnak értékelik saját egészségüket. A szülőktő́l kapott társas támogatás, valamint a szülooi értékrend elfogadása jelentős védőfaktornak bizonyultak (Pikó és Hamvai, 2009). Az önértékelés alappillérei a család támasza által alakulnak ki, a kortárskapcsolatok során erősödnek meg, majd fontos szerepet játszanak az életminőség percepciójában és az egészséges életmód kialakulásában.

$\mathrm{Az}$ általunk vizsgált mintában a földrajzi elhelyezkedés és az egészségvédő tényezők kapcsolatának elemzésénél a két csoport között szignifikáns különbség volt az élettel való elégedettséget illetően. Adataink szerint az egri diákok pozitivabban nyilatkoznak egészségi állapotukról, többet és rendszeresebben mozognak, mint a marosvásárhelyi dákok, mig testalkatukat kedvezőbben ítélik meg a marosvásárhelyi tanulók és a testtömegük szabályozására kevesebb erőfeszítést tesznek, mint egri kollegáik. Szignifikánsnak találtuk a különbséget a két csoport között az alkoholfogyasztás gyakoriságát illetően, de különbözőségeket mutatott az átlagok vizsgálata az egészségkárosító viselkedés más tényezői szempontjából is. A dohányzás az alkoholfogyasztás kipróbálási aránya nagyobb gyakoriságot valamint fogyasztási mennyisége is magasabb arányokat mutat az egri tanulók körében. A drogfogyasztás gyakorisága közel egyenlő mértéket mutat úgy a marosvásár- 
helyi, mint az egri diákok esetében (17\%). A földrajzi elhelyezkedés és a társas kontextus vizsgálata szignifikáns különbségeket talált az iskolai elfogadás és a tanárok tanuló iránti attitűdje szerint. Az egri tanulók pozitívabban viszonyulnak az iskolához, amelyben tanulnak, az osztálylégkört és az iskolai elfogadást is jobbnak itélik meg, és a tanáraikat is igazságosabbaknak látják. Az iskolai megterhelés szintje magasabb arányú a marosvásárhelyi tanulók esetében, de megitélésük szerint a tanáraikat nagyobb mértékben érdekli a személyiségük is. Más vizsgálatok eredményei (Lohaus és mtsai., 2004) hasonlóképpen alátámasztják hogy serdülőkorban az iskolai stresz szorosan összekapcsolódik az egészségre káros viselkedéssel.

A fizikai aktivitás rendszeressége a nyugati, fejlettebb kultúra velejárójaként tartható számon és igy a magyarországi serdülők számára is életmódbeli aktivitássá (egészségmagatartássá) válhatott. A kutatók szerint (Holder és mtsai. 2009) az aktív szabadidő (fizikai tevékenységek) pozitív összefüggést mutat a jól-léttel, a passzív szabadidő töltés (tv és videó nézés) viszont negatívan kapcsolódik a jól-lét percepciójához. Más eredmények szerint az énkép alakulását pozitivan befolyásolja a fizikai aktivitás (Kristjánsson és mtasi., 2010). A pedagógiai gyakorló munka során igen hasznos figyelembe venni az énkép és az önértékelés egyre szélesebb szerepét a gyerekek közösségi beilleszkedésében, és ennek érdekében olyan módszerek felhasználását, amelyek révén a gyerekek értéke-sebbeknek érezhetik magukat, befolyásolva ezáltal nemcsak a pozitivabb énkép kialakulását, de a tanulási kedv, iskola iránti pozitivabb viszonyulás stabilizálódását is. (Humphrey, 2004).

\section{Következtetések}

$\mathrm{Az}$ egri serdülók körében gyakoribb az egészségvédő magatartások száma (pl. fizikai aktivitás, élettel való elégedettség), mig a marosvásárhelyi mintában alacsonyabb az egészségre káros magatartásformák gyakorisága (pl. dohányzás, alkohol-fogyasztás). A kortárskapcsolatok támaszszerepe, de az iskolai megterhelés is mindkét minta esetében magas, az iskolai kontextus azonban kedvezóbb képet mutat az egri mintában, a marosvásárhelyi serdülók számára pedig a család támasza mérvadóbb. Vizsgálatunk aláhúzta a serdülőkori egészségmagatartás következményeinek szélesebb, interdiszciplináris szinten való megközelítési szükségességét és felmérését. Az egészséges életmód (a lakótársulások és közösségek szintjén történő) implikációinak mélyebb megértése elengedhetetlen ahhoz, hogy felmérhessük a helyi kultúrák, feltételek, körülmények szerepét az egészségmagatartásban és ennek következményeiben (Crockett, 1997).

Kutatásunk határaiként említhetjük a vizsgálatban részt vevô minta homogenitását (hasonló, elméleti irányultságú iskola típus), és a résztvevők nembeli homogenitását (többnyire lány). Ugyanakkor jelentősnek tartjuk megemlíteni, hogy az általunk választott minta a jobb elméleti iskolákból került ki, és ebből az okból kifolyólag kevesebb kockázati magatartás fordul elő, mint például a szakiskolákban.

A kutatás folytatása érdekében szükséges a minta elemszámának és életkori és nembeli rétegzettségének növelése valamint a kulturális különbözőség több indikátorának vizsgálata. Eredményeink felhasználhatóak a serdülőkori kockázati életmód csökkenését célzó programok megtervezéséhez, valamint az iskolai prevenciós tevékenységek alátámasztásához.

\section{Irodalom}

Albert-Lőrincz E. (2009): A drogfogyasztás prevenciója. Az integrált megelōzés elmélete és gyakorlata. Kolozsvári Egyetemi Kiadó, Kolozsvár

Albert-Lơrincz E. (2000): Az iskolai egészségnevelés aktuális kérdései., Ábrám Zoltán (szerk.) Életmód-egészség, Magyar Népfőiskolai Társaság, Preventio 
Egészségvédelmi Társaság, Marosvásárhely, 31-34

Andorka, R. (2006): Bevezetés a szociológiába. Második kiadás, Osiris Könyvkiadó, Budapest.

Benkő, Zs. (2005): A családok életmódját meghatározó társadalmi tényezők. Sženvedélybetegségek, VIII., 1: 54-57

Betancourt H, Flynn P. (2009): The psychology of health: physical health and the role of culture in behavior. In: Villarruel FA, Carlo G, Contreras Grau JM et al. (eds). Handbook of US Latino Psychology. Thousand Oaks, CA: Sage Publications.

Bourdieu, P. (1978): Társadalmi egyenlötlenségek újratermelódése. Gondolat Kiadó, Budapest.

Brassai, L., Pikó, B. (2007): Protektív pszichológiai jellemzők szerepe a serdülők egészséggel kapcsolatos magatartásában. Mentálhigiéné és Pszichoszomatika 8, 3, 211.227

Chen, Ch, Farruggia, S. (2002): Culture and Adolescent Development. Online Readings in Psychology and Culture, Unit 6. Retrieved from http://scholarworks.gvsu.edu/orpc/vol6/iss $1 / 2$

Cockerham, W. (2005): Health lifestyles theory and convergence of agency and structure. Journal of Health and Social Behavior, 41, 56-61.

Coleman, J. (1990): The nature of adolescence. In: Coleman, J. (ed.): Youth Policies in The 1990's, Routledge, Taylor \& Francis Books Ltd.

Crockett, L. J. (1997) Cultural, Historical, and Subcultural Contexts of Adolescence: Implications for Health and Development. In Schulenberg, J., Maggs, J. L., Hurrelmann, K. (eds.): Health Risks and Developmental Transitions During Adolescence. New York: Cambridge University Press.

Csibi, S., Csibi, M. (2013) Az önértékelés és a megküzdés szerepe a serdülők egészségvédő magatartásában, Mentálbigiéné és Pszichoszomatika 14(3): 281-295.
Currie, C., Roberts, C., Morgan, A., Smith, R., Settertobulte, W., Samdal, O., Rasmussen VB. (eds.) (2004): Young people's health in context. Health behaviour in School-aged Children (HBSC) study: International report from the 2001/2002 survey. WHO, Copenhagen.

Holder, M. D., Coleman B., Sehn, Z. L. (2009): The Contribution of Active and Passive Leisure to Children's Well-being. J Health Psychol 14: 378

Humphrey, N. (2004): The Death of the FeelGood Factor? Self-Esteem in the Educational Context. School Psychology International 25: 34

Kapitány Á., Kapitány G. (1996) Kultúrák találkozása - kultúraváltás. Savaria University Press, Szombathely.

Kollányi Zs., Imecs O. (2007): Az egéssségi állapot hatása a gazdasági teljesitóképességre és az. életminöségre. Demos Magyarország

Kopp, M., Pikó, B. (2003): A kultúra és az életminőség kapcsolata. In Vízi Sz. (szerk.) Civilizáacio és egészség. MTA Stratégiai Kutatások Sorozat, Budapest.

Kreuter, M.W., McClure, S.M. (2004): The role of culture in health communication. Annual Review of Public Health, vol. 25, pp. 439-455.

Kristjánsson, A. L., Sigfúsdóttir I. D., Allegrante J. P. (2010): Health Behavior and Academic Achievement Among Adolescents: The Relative Contribution of Dietary Habits, Physical Activity, Body Mass Index, and Self-Esteem. Health Educ Behav 37: 51

Lohaus, A., Klein-Hessling, J., Ball, J., Wild, M (2004): The Prediction of Health-related Behaviour in Elementary School Children. J Health Psychol 9: 375

Maggs, J. L., Schulenberg, J., \& Hurrelmann, K. (1997). Developmental transitions during adolescence: Health promotion implications. In J. Schulenberg, J. L. Maggs, \& K. Hurrelmann (Eds.): Health risks and developmental transitions 
during adolescence. New York: Cambridge University Press.

Michael, K. and Ben-Zur, H. (2007): Risk-taking among Adolescents: Associations with Social and Affective Factors. Journal of Adolescence 30(1): 17-31.

Papp Z. A. (2005) Időhasználat és iskolai teljesítmény a romániai magyar középiskolai kultúrában. In: Gábor Kálmán - Veres Valér (szerk.) Erdélyi fiatalok helyzetképe az ezredforduló után. Belvedere, Szeged, 54-74.

Pikó B. (2002): Egészségszociológia. Új Mandátum, Budapest.

Pikó B. (2002): Fiatalok pszichoszociális egészsége és rizikómagatartása a társas támogatás tükrében. Osiris Kiadó, Budapest.Pikó B. (2010): Védófaktorok nyomában. A káros szenvedélyek megelörése és egészségfejlesztés serdïlókorban. L 'Harmattan Kiadó, Budapest.

Pikó, B., Hamvai, Cs. (2009): Az egészségi állapot önértékelését befolyásoló szülői és egyéni pszichológiai védôfaktorok vizsgálata serdülôk körében. Mentálhigiéné és Pszichoszomatika 10, 3, 239-24

Rosenberg, M. (1965): Society and adolescent selfimage. Princeton University Press: Princeton, NJ.

Sallai, H. (2005): Serdülők szubjektív jólléte: a családban és a baráti kapcsolatban észlelt igazságosság és az igazságos világba vetett hit szerepe. Mentálhigiéné és Pszichoszomatika 6, 4, 295.315
Spéder, Zs., Kapitány, B. (2002): A magyar lakosság elégedettségének meghatározó tényezői, nemzetközi összehasonlításban. In Kolosi-Tóth-Vukovich (szerk.) Társadalmi riport 2002. Tárki, Budapest, 162-172.

Susánszky É. Konkoly-Thege B., Stauder A., Kopp M. (2006): A WHO Jól-lét kérdőív rövidített (WBI-5) magyar változatának validálása a Hungarostudy 2002 országos lakossági egészségfelmérés alapján. Mentálhigiéné és Pszichoszomatika 7, 3, 247.255

Torsheim, T., Välimaa, R., Danielson, M. (2004): Health and well-being. In: Currie, C., Roberts, C., Morgan, A., Smith, R., Settertobulte, W., Samdal, O., Rasmussen VB. (eds.): Young people's health in context. Health behaviour in School-aged Children (HBSC) study: International report from the 2001/2002 survey. WHO, 2004, 55-62.

Tyc, V. L., Nuttbrock-Allen, D., Klosky J. L., Ey S. (2004): An exploratory study to investigate cognitive-motivational variables as predictors of health behaviours in adolescents. Health Education Journal 63: 293

Williams, J. M., Currie, C. (2000): Self-Esteem and Physical Development in Early Adolescence: Pubertal Timing and Body Image. The Journal of Early Adolescence 20: 129

Woodgate, R. L., Leach, J. (2010): Youth's Perspectives on the Determinants of Health. Qual Health Res 20: 1173 